\title{
Analysis of the Effects of Climate Change on Crop Output in Nigeria
}

\author{
Dominic Z. Agba1 ${ }^{*}$, Sunday O. Adewara1', Joseph I. Adama1', Kelvins T. Adzer², Gabriel 0. Atoyebi1 \\ ${ }^{1}$ Department of Economics, College of Business and Social Sciences, Landmark University, Omu Aran, Kwara State, Nigeria \\ ${ }^{2}$ College of Education, Katsina-Ala, Benue State, Nigeria \\ Email: *agba.dominic@lmu.edu.ng, *agbadominic@gmail.com
}

How to cite this paper: Agba, D.Z., Adewara, S.O., Adama, J.I., Adzer, K.T. and Atoyebi, G.O. (2017) Analysis of the Effects of Climate Change on Crop Output in Nigeria. American Journal of Climate Change, 6, 554-571.

https://doi.org/10.4236/ajcc.2017.63028

Received: April 5, 2017

Accepted: September 24, 2017

Published: September 27, 2017

Copyright (c) 2017 by authors and Scientific Research Publishing Inc. This work is licensed under the Creative Commons Attribution International License (CC BY 4.0).

http://creativecommons.org/licenses/by/4.0/

\begin{abstract}
This study investigates the effects of climate change factors and non-climate change factors on crop output in Nigeria. Empirical research approach was adopted with the use of secondary sources of time series annual data obtained from reputable sources for the period 1980-2013. Error Correction Mechanism was used for the analysis. It was found that in the short run, only rainfall tested significantly positive to crop output among the climate change factors but there is evidence of significant effects of all climate change factors on crop output in the long-run. For example, temperature, carbon dioxide emission, carbon emission and rainfall were tested significantly to crop output. Furthermore, non-climate change factors like economically active population, gross capital formation, and land area equipped for irrigation were significantly positive to crop output. To forestall the effects of climate change on crop output, the study recommends that policy makers should formulate policies that will aid farmers towards adaptation practices in farming that can mitigate the effects of climate change. Furthermore, governments and other relevant agencies should also design programmes that can motivate the masses to increase their involvement in crop production.
\end{abstract}

\section{Keywords}

Climate Change, Crop Output, Agriculture, Cointegration, Error Correction Model, Nigeria

\section{Introduction}

There is a growing scientific consensus that human activities have substantially contributed to the increase in atmospheric concentration of greenhouse gases. The increase has been enhancing the natural greenhouse effect which has in turn 
led to increased warming of the earth's surface and atmosphere. The rise in temperature has resulted in the frequency and intensity of extreme weather conditions causing climate change. However, even though climate change is a global phenomenon, the negative impact is unevenly felt depending on the adaptive capacity of individual nations. African nations are most exposed to climate change because they lack the requisite adaptive wherewithal to cope with it.

The Intergovernmental Panel on Climate Change (IPCC) stated that climate change is emerging as one of the cardinal challenges of the $21^{\text {st }}$ century [1]. Human induced climate change resulting from increase in the concentration of greenhouse gasses (GHGs) in the atmosphere and food insecurity are too related threats facing mankind in the $21^{\text {st }}$ century. IPCC observed the unrelenting emission of greenhouse gasses into the atmosphere [2]. The gasses emitted into the atmosphere include carbon dioxide $\left(\mathrm{CO}_{2}\right)$, methane $\left(\mathrm{CH}_{4}\right)$, nitrous oxide $\left(\mathrm{N}_{2} \mathrm{O}\right)$, Hydroflourocarbons (HFCs) Perfluorocarbons (PFCs) and Carbonhexafluoride $\left(\mathrm{CF}_{6}\right)$. All these gasses were unambiguously articulated in the Kyoto protocol. $\mathrm{CO}_{2}$ among the gasses increased over the per capita income and population and thereby contributes to over $40 \%$ of the total emission of GHGs [3].

Powered by solar radiation, the climate system is a complex, interactive system consisting of the atmosphere, land surface, snow and ice, oceans and other bodies of water and living things. It evolves over time under the influence of its own internal dynamics and due to changes in external factors that affect climate called "forcings". External forcings include natural phenomena (e.g., volcanic eruptions and solar variations) as well as anthropogenic (man-made) changes that alter the balance between incoming (solar) short wave solar radiation and outgoing long wave radiation. This radiation is made possible through feedback mechanism to which the climate system responds both directly and indirectly. As a feedback mechanism, radiative forcings, a measure that altering the balance of incoming and outgoing energy in the earth atmosphere system, has some effects on the earth surface while positive forcings tend to warm the earth surface, negative forcings tend to cool it [4].

Warming of the climate system is increasing in recent times and the earth's temperature is highly variable. Warming trend over the last 50 years is nearly twice that of the last 100 years, and even higher over the past twenty five (25) years [5]. Rising average sea levels (from ocean warming and widespread melting of snow and ice) also provide evidence of a warming of the climate system.

Reports have shown that increasing global temperature is likely to boost agricultural production in the temperate regions and it is expected to reduce yields in the tropical regions of the world [6]. It is projected that many African regions will suffer from drought and floods with greater frequency and intensity in the nearest future [7]. The report further observed that the rise in average temperature between 1980/1999 and 2080/2099 would be in the range of $3^{\circ} \mathrm{C}-4^{\circ} \mathrm{C}$ across the entire African continent which is 1.5 times more than global level. The report continued that Africa's Mediterranean region will experience a de- 
crease in precipitations during the century. These dry conditions would affect the northern boundary of the Sahara where Africa lies.

Agriculture is the mainstay of majority of households in Nigeria and a significant determinant of the Nigerian economy. The significance of the agricultural sector cannot be overemphasized as it a catalyst for food production, contributing to the gross domestic product, provision of employment and raw materials for agro allied industries, and generation of foreign earnings. A sectorial analysis in 2006 of the real GDP indicated that the agricultural sector contributed about 42 percent compared with $41.2 \%$ percent in 2005 [8]. Similarly the growth rate of the contribution of the agricultural sector to the GDP at 1990 constant basic prices grew from 4.2 percent in 2002 to 7.2 percent in 2006, 7.21 percent in 2007, 6.2 percent in 2008, 5.9 percent in 2009, 4.2 percent in 2002 to 4.12 percent in 2014. The agricultural sector also employed over 60 percent of the total labour force in Nigeria in 1999 [9].

Crop production takes a significant part of agricultural production in Nigeria. Generally there are many factors influencing crop production and these include soil, relief, climate and diseases among others. In relation to climate, rainfall is one of the dominant controlling variables in tropical agriculture since it supplies soil moisture for crops. Nigeria's wide range of climate variation allows it to produce a wide variety of cash and food crops [10]. Climate is an important resource to crop production in Nigeria especially in the rainforest zone of Nigeria as farmers depend largely on rain for agriculture. Studies indicate that Africa's agriculture is negatively affected by climate change, and that adaptation is one of the policy options for reducing the negative impact of climate change [11] [12].

It is necessary to note the fact that food production can no longer keep pace with population growth in Nigeria, and food shortage is believed to be largely caused by several factors including climate change. Over $60 \%$ of the Nigerian populace depends so much on agriculturally related activities for sustenance and crop production and processing takes a significant aspect of agriculturally related activities in Nigeria. For instance, crop production and processing contributes over $80 \%$ of agricultural GDP and more than $48 \%$ of total non-oil GDP in Nigeria (CBN, [13]). Ayinde, Muche, Olatunji [14] pointed out that climate fluctuation is putting Nigeria's agricultural system under serious threat and stress. This implies that rural sustainability and food security is under serious threat as crop production takes significant aspect of agricultural activities in $\mathrm{Ni}$ geria. Given this background, this study attempts to answer the following questions: 1) What is the impact of climate change on crop output in Nigeria? 2) What other factors influence crop output in Nigeria? This study is an attempt to contribute to existing literature on climate change effects on crop output.

\section{Literature Review/Theory}

\subsection{Conceptual Literature and Theoretical Background}

Crop production is a branch of agriculture that deals with growing crops for use 
as food and fiber. It depends on the availability of arable land and is affected in particular by yields, macroeconomic uncertainties, as well as consumption patterns; it also has a great incidence on agricultural commodity prices. The importance of crop production is related to harvested areas, returns per hectare (yields) and quantities produced. Crop yields are the harvested production per unit of harvested area for crop products. In most of the cases yield data are not recorded, but are obtained by dividing the production data by the data on area harvested. The actual yield that is captured on farm depends on several factors such as the crop's genetic potential, the amount of sunlight, water and nutrients absorbed by the crop, the presence of weeds and pests. Crop production is measured in tonnes per hectare, in thousand hectares and thousand tonnes [15].

According to IPCC [4], climate change is a change in the state of climate that can be identified by changes in the mean and or the variability of its properties that persist for an extended period typically decades or longer. Also, United Nations Framework Convention on Climate Change UNFCCC [16]. Attributes climate change directly or indirectly to human activities (anthropogenic factors) that alter the composition of the global atmosphere and are in addition to natural climate variability observed over a comparable period of time. Climate is the statistics of weather, usually over a 30-year interval. It is measured by assessing the patterns of variation in temperature, humidity, atmospheric pressure, wind, precipitation, atmospheric particle count and other meteorological variables in a given region over long periods of time [17]. Climate differs from whether in that weather only describes the short term conditions of these variables mentioned above in a given period of time.

There are many theories of climate change. The first theory of climate change reviewed in this study is known as Anthropogenic Global Warming, or AGW, [18] contends that human emissions of green-house gases, principally carbondioxide $\left(\mathrm{CO}_{2}\right)$, methane, and nitrous oxide, are causing a catastrophic rise in global temperature. The mechanism whereby this happens is called the enhanced greenhouse effect. Another theory of climate change is called Global Bio-thermostat which holds that negative feedbacks from biological and chemical processes entirely or almost entirely offset whatever positive feedbacks might be caused by rising $\mathrm{CO}_{2}$. These processes act as a "Global Bio-thermostat" keeping temperatures in equilibrium. The scientific literature contains evidence of at least eight such feedbacks which includes Carbon Sequestration, Carbonyl Sulfide, Diffuse Light, Iodocompounds, not counting cloud formation, dimethyl sulfide and other Aerosols.

Another theory of climate change is called Human Forcings spearheaded by [4], it holds that mankind's greatest influence on climate is not its greenhouse gas emissions, but its transformation of Earth's surface by clearing forests, irrigating deserts, and building cities. According to [19], although the natural causes of climate variations and changes are undoubtedly important, the human influences are significant and involve a diverse range of first-order climate forcings, 
including but not limited to, the human input of carbon dioxide $\left(\mathrm{CO}_{2}\right)$. Short descriptions of some of these "human forcings" other than green-house gases follow.

According to Gray [20], the lead proponent of "Ocean Currents Theory" which contends that global temperature variations over the past century and a half, and particularly the past 30 years, were due to the slow-down of the ocean's Thermohaline Circulation (THC).Ocean water is constantly transferred from the surface mixed layer to the interior ocean through a process called ventilation. The ocean fully ventilates itself every 1000 to 2000 years through a polar region (Atlantic and Antarctic) deep ocean subsidence of cold-saline water and a compensating upwelling of warmer less saline water in the tropics. This deep ocean circulation, called the Meridional Overturning Circulation (MOC), has two parts, the primary Atlantic Thermohaline Circulation (THC) and the secondary Surrounding Antarctica Subsidence (SAS). Paleo-proxy data and meteorological observations show there have been decadal to multi-century scale variations in the strength of the THC over the past thousand years, when the THC circulation is stronger than normal the earth-system experiences a slightly higher level of evaporation-precipitation ( 2 percent). When the THC is weaker than normal, as it is about half the time, global rainfall and surface evaporation are reduced about 2 percent.

Bast, J. L. [21] presented a theory of climate change as propounded in 1600s by Johannes Kepler ${ }^{1}$ called the theory of Planetary Motion. The theory states that most or all of the warming of the latter part of the twentieth century can be explained by natural gravitational and magnetic oscillations of the solar system induced by the planet's movement through space. These oscillations modulate solar variations and/or other extraterrestrial influences of Earth, which then drive climate change. An extraterrestrial influence on climate on a multi-millennial time-scale associated with planetary motion was first suggested by a Serbian astrophysicist, Milutin Milankovitch, and published in 1941. More recent discoveries have enabled scientists to accurately measure these effects on climate. Earth's orbit around the sun takes the form of an ellipse, not a circle, with the planet passing farther away from the sun at one end of the orbit than at the other end. The closest approach of the planet to the sun is called "perihelion" and the farthest is called "aphelion". Perihelion now occurs in January, making northern hemisphere winters slightly milder. The change in timing of perihelion is known as the precession of the equinoxes, and it occurs every 22,000 years.

\subsection{Empirical Literature on Climate Change and Crop Production}

This section provides literature on climate change and its effect on agriculture. At the global level, a country may generate global warning through the emission of industrial pollutants and destroy the ozone layer which might affect other

${ }^{1}$ Kepler's life is summarized on pages 523-627 and Book Five of his magnum opus, Harmonice Mundi (harmonies of the world), is reprinted on pages 635-732 of On the Shoulders of Giants: The Great Works of Physics and Astronomy (works by Copernicus, Kepler, Galileo, Newton, and Einstein). Stephen Hawking, ed. 2002 ISBN 0-7624-1348-4 
countries that might not be emitting as much leading to accumulation of Green House Gasses (GHGs) in the atmosphere that creates concern for the globe. Such pollution is termed trans-boundary externality [22].

On the global context externalities are specified in terms of distinction between polluting and victim countries. However, Mendelsohn and Dinar [23] have examined the impacts of climate change on agriculture in India and Brazil. They employed three different methods for the analysis namely; the Ricardian method, Agro-economic model and agro-ecological zone analysis. Environmental factors such as farm performance, land value or net income and traditional economic inputs which are land and labour, and support system such as infrastructure were used as explanatory variables in the model. Unlike most studies, this analysis pointed out the significance of adaptation. They argue that farmers will adapt to new conditions due to climate change by making production decisions which are in their own best interest. Crop choice is one of the examples of farmers' adaptation to warmer weather in the study. Wheat, corn and rice are three crops for example used since the regions in which they grow depend on the temperature. As temperature gets warmer wheat farmers' switch from production of wheat to corn for enhanced profit making. Later, if temperature gets warmer again enough to lose profits, farmers adapt to warmer weather thus switch to rice from corn. The results of the Ricardian method; agro-economic model, and agro-ecological zone analysis showed that increase in temperature will decrease crop production especially the crops grown in cool areas such as wheat. However, the authors argued that the result of the Ricardian method suggest that farmers ability to adapt to new conditions will mitigate the impact of climate change in the long run while the agro-economic model and agro-ecological zone analysis would be more suitable for short run analysis since the adaptations is not included in the models. Mathauda, Mavi, Bhangoo, and Daliwal [24] investigated the effects of temperature change on rice yield in the Punjab region in India by using the Ceres Rice simulation model between 1970-1990. They stratified the weather scenarios by 5 different conditions which are normal weather, slight warm ( 0.5 increase), and extreme warm condition $\left(2^{\circ} \mathrm{C}\right.$ increase) in the simulation model. The model predicted that temperature increase decreases rice yield by $3.2 \%$ in slight warm, $8.2 \%$ in greater warm, and $8.4 \%$ in extreme warm condition compared to normal condition scenario. The result also showed that an increase in temperature negatively affects not only rice production but also other rice attributions such as biomass, crop duration and straw yield. Torvanger, Twena, and Romstad [25] analyzed climate change in Norway for the period 1958-2001. The study employed time series data with biophysical statistical model to examine the dynamic linkages between yields of potatoes, barley, oats, wheat and climate change variables such as temperature and precipitation. The study found that there is a positive impact on yields from temperature in $18 \%$ of the crops. The effect is found to be strongest for potatoes. Regionally, the study 
revealed that temperature is likely to be a more important limiting factor for crop growth in Northern Norway than other regions. The effect of precipitation is found to be negative in about $20 \%$ of the cases.

Basak, Ali, Islamand Rashid [26] analysed climate change impacts on rice production in Bangladash by using simulation model. The model specifically focused on Boro rice production which amounts to $58 \%$ of the total rice production during 2008 in Bangladesh to estimate to estimate the effects of future climate change, soil and hydrologic characteristics of the locations, typical crop management practices, and traditional controlled in the simulation model called DASAT (Decision Support System for Agrotechnology Transfer). The simulation results shows that rice production varies in different locations for different climatic conditions and hydrological properties of soil although same Boro rice was used in all areas. The model also indicates that rice production decreased drastically from $2.6 \%$ to $13.6 \%$ and from $0.11 \%$ to $28.7 \%$ when the maximum temperature was increased by $2^{\circ} \mathrm{C}$ and $4^{\circ} \mathrm{C}$. Although the simulation model shows that a drop in minimum temperature also reduces the rice yield. It suggests that increases in temperature causes more damage in production. The model also found some positive effects of $\mathrm{CO}_{2}$ concentration on rice yield but the impact was little compared to that of temperature change.

In Nigeria, Agboola and Ojeleye [27], examined the impact of climate change in Ibadan Nigeria. The study adopted both primary and secondary sources of data. For the secondary source of data, time series data covering 30 years were collected on climatic variables and the analysis was done with bivariate Chi-square and ANOVA supported by graphical illustrations. The study revealed that farmers have experienced reduced crop yield on food crop production due to reduction in rainfall and relative humidity as well as increase temperature.

Terfa [28] studied "climate change and food supply in Nigeria" the study adopted the use of generalized error correction model using time series data sourced from CBN statistical bulletin and world bank country data from 1970 to 2009 on variables like food output, temperature and rainfall. The study found that both temperature and rainfall had an insignificant influence on food supply and the increase in temperature leads to decrease in food supply while increase in rainfall leads to increase in food supply.

Eregha, Babatolu, and Akinnubi [29] did a study titled "Climate Change and Crop Production in Nigeria: An Error Correction Modeling Approach" the work used time series data sourced from Food and Agricultural organization Database, 2012 Central Bank Statistical Bulletin 2011 and data from World Development indicator Database 2012. The technique of analysis was done with the Error Correction technique. The data coverage was 1970-2009. The study used variables like crop output, temperature and rainfall as well as carbon emission. The study found that temperature and had a significantly negative influence on crop production, while rain was found to have a significantly positive effect while carbon emission was found to have a significantly negative impact on crop pro- 
duction in Nigeria.

\subsection{Gap in Literature}

A careful study of literature available shows that most models of climate change only looks at temperature and rainfall. Only one study also included carbon emission. No single study has included enough variables in its model that could adequately explain the dependent variable (crop output). This study therefore included nine variables in its model, one dependent and eight explanatory variables to make the model more robust in explaining crop output in Nigeria. The additional variables included in this study were Carbon Emission due to Manufacturing and Industrial activities, Gross fixed Capital Formation, Agricultural Machines and Tractors, Economically Active Population in Agriculture and Land Area Equipped for Irrigation.

\section{Methodology}

\subsection{Sources of Data}

Rainfall data was sourced from Central Bank Statistical Bulletin [30] and computed to arrive at annual averages. Also, data on temperature was sourced and extrapolated from the work of [31]. Data on carbon dioxide due to manufacturing and industrial activities in Nigeria was sourced from World data Atlas [32]. Data on Gross fixed Capital Formation, Agricultural Machines and Tractors, Economically Active Population in Agriculture, Land Area Equipped for Irrigation were sourced from African Development Indicator, Crop Production index and Carbondioxide Emissions were sourced from [33]. The data set used in this study ranges from 1980-2013.

\subsection{Theoretical Framework}

The empirical framework follows the derivation in Bond, Leblebicioglu, Schiantarelli [34]. Though, the derivation of this framework was used for panel study, its theoretical explanation could be used for time series studies as it best fits in explaining the dynamic linkages between climate variables and crop production. This is presented as follows. Consider the following simple economy:

$$
\begin{gathered}
Y_{t}=\mathrm{e}^{\beta T_{t}} A_{t} L_{t} \\
\Delta A_{t} / A_{t}=g+\gamma_{t}
\end{gathered}
$$

where $Y$ is aggregate output, $L$ measures population, $A$ measures labor productivity, and $T$ measures climate. Equation (1) captures the level effect of climate on production; that is, the effect of current temperature or precipitation on crop yields. Equation (2) captures the growth effect of climate; i.e. the effect of climate on features such as institutions that influence productivity growth. Taking logs in the production function and differencing with respect to time, we have the dynamic growth equation:

$$
g_{t}=g+(\beta+\gamma) T_{t}-\beta_{t-1}
$$


where $g t$ is the growth rate of per-capita output. The "level effects" of climate shocks on output, which come from Equation (1), appear through $\beta$. The "growth effects" of climate shocks, which come from Equation (2), appear through $\gamma$. The growth equation in (3) allows separate identification of level effects and growth effects through the examination of transitory weather shocks. In particular, both effects influence the growth rate in the initial period of the shock. The difference is that the level effect eventually reverses itself as the climate returns to its prior state. For example, a temperature shock may reduce agricultural yields, but once temperature returns to its average value, agricultural yields bounce back. By contrast, the growth effect appears during the climate shock and is not reversed: a failure to innovate in one period leaves the country permanently further behind. The growth effect is identified in (3) as the summation of the climate effects over time.

\subsection{Model Specification and Analytical Technique}

The analytical technique used in this study is the Error Correction model. The tight linkage between cointegration and error correction models stems from the Granger representation theorem. According to this theorem, two or more integrated time series that are cointegrated, have an error correction representation, and two or more time series that are error correcting are cointegrated [35]. This technique of analysis is adopted because it provides evidence of both shortrun and long-run association and response to shocks within the economy. The model presented here is in line with economic theory which specifies that the quantity of crop output in any one country depends on the set of factors/variables presented below as evidenced by the studies of Mathauda, Mavi, Bhangoo, and Daliwal [24], Terfa [28] etc. The Linear model is specified as follows

$$
\mathrm{CRPI}=\mathrm{f}\left(\mathrm{RAIN}, \mathrm{TEMP}, \mathrm{CARBE}, \mathrm{CO}_{2} \mathrm{E}\right)
$$

where, CRPI $=$ Crop Production index or Crop Output RAIN $=$ Rainfall $(\mathrm{cm})$

TEMP $=$ Temperature (measured in degrees)

$\mathrm{CARBE}=$ Carbon Emission due to Manufacturing and Industrial activities (MT per capital)

$\mathrm{CO}_{2} \mathrm{E}=$ Carbon dioxide Emission (million MT)

Equation one captures only the climate change factors for which data was available. To have a better picture of the factors influencing crop production, other non-climate change factors were included as specified in the objectives of this work. This takes us to equation two (2) which provides a more robust idea of the model used. Where

$$
\text { CRPI }=\text { F(RAIN, TEMP, CARBE, CO2E, EAPA, LAEI, GCF, GMT })
$$

$\mathrm{GCF}=$ Gross fixed Capital Formation (\% of GDP)

AGMT = Agricultural Machines and Tractors (100 sq km of arable land)

EAPA $=$ Economically Active Population in Agriculture (Number)

LAEI $=$ Land Area Equipped for Irrigation (hectares) 
The econometric version of the model will be specified as follows

$$
\begin{aligned}
\mathrm{CRPI}_{\mathrm{t}}= & \alpha+\alpha_{1} \mathrm{CO}_{2} \mathrm{E}_{t}+\alpha_{2} \mathrm{EAPA}_{t}+\alpha_{3} \mathrm{LAEI}_{t}+\alpha_{4} \mathrm{CARBE}_{t}+\alpha_{5} \mathrm{GCF}_{t} \\
& +\alpha_{6} \mathrm{TEMP}_{t}+\alpha_{7} \mathrm{RAIN}_{t}+\alpha_{8} \mathrm{AGMT}_{t}+\mu_{t}
\end{aligned}
$$

Model 3 is the long run version of the error correction model which explains the relationship among variables in the long-run. The short run version of the error correction model is specified as follows.

$$
\begin{aligned}
\Delta \mathrm{CRPI}_{t}= & \alpha+\alpha_{1} \Delta \mathrm{CO}_{2} \mathrm{E}_{t}+\alpha_{2} \Delta \mathrm{EAPA}_{t}+\alpha_{3} \Delta \mathrm{LAEI}_{t}+\alpha_{4} \Delta \mathrm{CARBE}_{t} \\
& +\alpha_{5} \Delta \mathrm{GCF}_{\mathrm{t}}+\alpha_{6} \Delta \mathrm{TEMP}_{t}+\alpha_{7} \Delta \mathrm{RAIN}_{t}+\alpha_{8} \Delta \mathrm{AGMT}+\mathrm{ec}_{t-1}+\mu_{t}
\end{aligned}
$$

$\mu=$ Error term $t=$ Time parameter $t-1=$ Previous time periodec $=$ Error correction term $\Delta=$ difference operator $\alpha=$ Constant $\alpha_{1}-\alpha_{8}=$ Coefficients of independent Variables

Model 4 is specified with the error correction term. It explains the rate of adjustment within the system per annum if there is a shock. The error correction term must be negative show that the system is converging in the longrun, in order words the system will return to equilibrium in twelve months (Table 1).

\subsection{Preliminary Tests}

Due to the fact that the variables in the model are time series it is necessary to test for their order of stationarity. This study used the augmented Dikey-Fuller test (ADF) to check the unit root properties of the series. The presence of a long run relationship among the variables was tested using Engle-granger cointegration method on the basis that the variables are integrated of order one, i.e., I(1). The method specifies that though the series may not be stationary at first difference I(1), there can still be a long run relationship among them if their residual is stationary at levels $\mathrm{I}(0)$. The test of long run relationship among the series is called cointegration.

\section{Results and Discussions}

This section is the presentation and analysis of data. The statistical package used is Stata $12^{\text {th }}$ edition and procedure of the analysis that led to these results is already described in Section 3.1. The results are as follows

\subsection{Results of Unit Root Tests}

Results in Table 2 shows that all the series tested became stationary at first difference. A further test needs to be carried out in order to ensure that there is a long-run relationship among variables. To achieve this, the study used the

Table 1. Theoretical expectations.

\begin{tabular}{ccccccccc}
\hline Coefficient of variable & RAIN & TEMP & CARBE & $\mathrm{CO}_{2} \mathrm{E}$ & GCF & AGMT & EAPA & LAEI \\
\hline Expected sign & $>0$ & $<0$ & $<0$ & $<0$ & $>0$ & $>0$ & $>0$ & $>0$ \\
\hline
\end{tabular}

Source: Authors computation (2017). 
Table 2. Unit Root Test (ADF) order of stationarity.

\begin{tabular}{cccccccccc}
\hline Statistic & CRPI & TEMP & RAIN & CARBE & LAEI & EAPA & AGMT & GCF & CO $_{2}$ E \\
\hline $\begin{array}{c}\text { ADF test } \\
\text { statistic }\end{array}$ & -2.912 & -3.900 & -4.800 & -3.334 & -4.722 & -3.812 & -5.001 & -3.350 & -3.211 \\
$\mathbf{1} \%$ & -2701 & -3.696 & -4.001 & -2.911 & -3.711 & -3.200 & -3.500 & -3.702 & -3.113 \\
$\mathbf{5} \%$ & -2.811 & -2.978 & -3.500 & -3.001 & -3.622 & -3.110 & -4.110 & -2.980 & -3.201 \\
$\mathbf{1 0} \%$ & -2.900 & -2.620 & -4.102 & -3.101 & -3.211 & -3.602 & -3.020 & -2.662 & -3.08 \\
$\begin{array}{c}p \text {-value } \\
\text { Order of }\end{array}$ & 0.00121 & 0.0020 & 0.0124 & 0.0101 & 0.0049 & 0.0003 & 0.0010 & 0.0128 & 0.0420 \\
integration & I (1) & I (1) & I (1) & I (1) & I (1) & I (1) & I (1) & I (1) & I (1) \\
\hline
\end{tabular}

Source: Results computed from Stata $12^{\text {th }}$ edition (2017).

Augmented Dickey Fuller test which specifies that the residuals of the regression must be stationary at first difference.

\subsection{Results of Engle-Granger Test of Cointegration}

This test investigates long run relationship among variables through Unit root test of residuals.

Results in Table 3 above shows that there is a long run relationship among variables since the residual of the regression has shown that the absolute value of test statistic is higher than that of its critical value at $1 \%, 5 \%$ and $10 \%$ critical value, and a probability value of less than $5 \%$. This shows that the variables are cointegrated in the long run, hence the minimum condition for the use of Error Correction Model.

Table 4 below shows that in the short run only agricultural machines and tractors (AGMT), economically active population in agriculture (EAPA), rainfall (RAIN), have indicated a significant influence on crop output (CPRI) at 95\% confidence level, the rest of the variables tested insignificant to crop output. Also the coefficients of all the variables are in line with apriori expectations except AGMT. The error correction term which is negative, shows that the economy converges or will returns to equilibrium at the rate of $23 \%$ per annum if there is a shock within the system. In the short-run, among the climate change factors, the results show that only rainfall has a significant effect on crop output.

Table 5 presents the results of long-run model of the error correction mechanism. Whereas in the short run model only rainfall, agricultural machines and tractors, and economically active population in agriculture were significantly positive to crop output, the long-run equilibrium of the model shows that almost all variables tested significant to crop output at $95 \%$ confidence level while Gross capital formation GCF and TEMP were significant at 90\% confidence level within the period under investigation. This implies that as gross capital formation increases crop yield will also increase while as temperature increases crop yield will decrease. The implication is that stakeholders must begin to develop and encourage adaptation strategies for crop production methods so as to avoid a fall in crop output in future. It is necessary to note that a reduction in output of 
Table 3. Results of interpolated dickey-fuller test number of obs $=33$.

\begin{tabular}{lcccc}
\hline & Test statistic & $\mathbf{1 \%}$ critical value & $\mathbf{5 \%}$ critical value & $\mathbf{1 0 \%}$ critical value \\
\hline $\mathrm{Z}(\mathrm{t})$ & -5.366 & -3.696 & -2.978 & -2.620 \\
\hline
\end{tabular}

MacKinnon approximate $p$-value for $Z(t)=0.0000$. Source: Results obtained from Stata $12^{\text {th }}$ edition $(2017)$.

Table 4. Results of short run model of error correction mechanism.

\begin{tabular}{cccccccc}
\hline Source & SS & Df & MS & & Number of obs & 33 \\
\hline Model & $10,381.8335$ & 9 & 1153.53706 & & F( 9, 23) & 61.17 \\
Residual & 433.761082 & 23 & 18.8591775 & & & Prob > F & 0.0000 \\
Total & $10,815.5946$ & 32 & 337.987331 & & & R-squared & 0.9599 \\
& & & & & & Adj R-squared & 0.9442 \\
& & & & & & Root MSE & 4.3427 \\
dCRPI & Coef & Std. Err. & T & $p>|t|$ & {$[95 \%$ Conf. Interval] } & \\
dAGMT & -1.218416 & 0.6987755 & -1.74 & $0.095^{*}$ & -2.663944 & 0.227111 & \\
dCO2E & -8.554829 & 7.694169 & -1.11 & 0.278 & -24.47143 & 7.361771 & \\
dEAPA & $7.87 \mathrm{e}-06$ & $4.14 \mathrm{e}-07$ & 18.98 & $0.000^{* * *}$ & $7.01 \mathrm{e}-06$ & $8.72 \mathrm{e}-06$ & \\
dLAEI & 0.0000256 & 0.0000215 & 1.19 & 0.246 & -0.0000189 & 0.0000701 & \\
Drain & 0.2427112 & 0.0806186 & 3.01 & $0.006^{* * *}$ & 0.0759388 & 0.4094835 & \\
dTEMP & 0.2206473 & 0.250736 & 0.88 & 0.388 & -0.2980397 & 0.7393343 & \\
dCARBE & -0.0753484 & 0.1143685 & -0.66 & 0.517 & -0.3119378 & 0.1612409 & \\
Dgcf & 0.000037 & 0.0001068 & 0.35 & 0.732 & -0.0001839 & 0.0002578 & \\
ect L1 & -0.2356313 & 0.1120989 & -2.10 & $0.047^{* *}$ & -0.4675255 & -0.003737 & \\
_cons & 2.036069 & 0.8443183 & 2.41 & 0.024 & 0.289463 & 3.782674 & \\
\hline
\end{tabular}

Source: Results obtained from Stata $12^{\text {th }}$ edition (2017). ${ }^{* * *},{ }^{* *},{ }^{*}$ indicates significant at $p<0.01, p<0.05$, and $p<0.1$ respectively.

Table 5. Results of long run model of error correction mechanism.

\begin{tabular}{cccccccc}
\hline Source & SS & Df & MS & & & Number of obs & 34 \\
\hline Model & $26,074.0771$ & 8 & 3259.25964 & & & F (8, 25) & 17.70 \\
Residual & 4603.68983 & 25 & 184.147593 & & & Prob > F & 0.0000 \\
Total & $30,677.767$ & 33 & 929.629302 & & & R-squared & 0.8499 \\
& & & & & & Adj R-squared & 0.8019 \\
& & & & & & Root MSE & 13.57 \\
CRPI & Coef & Std. Err & T & $p>|t|$ & [95\% Conf. Interval] & \\
CO2E & -51.58716 & 14.56267 & -3.54 & $0.002^{* *}$ & -81.57954 & -21.59479 & \\
EAPA & $7.53 \mathrm{e}-06$ & $1.62 \mathrm{e}-06$ & 4.66 & $0.000^{*}$ & $4.20 \mathrm{e}-06$ & 0.0000109 & \\
LAEI & 0.0002349 & 0.000059 & 3.98 & $0.001 *$ & 0.0001134 & 0.0003563 & \\
CARBE & -0.7131672 & 0.1847757 & -3.86 & $0.001 *$ & -1.09372 & -0.3326146 & \\
GCF & 0.0007453 & 0.0003755 & 1.98 & $0.058^{* *}$ & -0.000028 & 0.0015186 & \\
TEMP & 1.429359 & 0.8155287 & 1.75 & $0.092 * * *$ & -0.250254 & 3.108971 & \\
RAIN & 0.5485709 & 0.2632852 & 2.08 & $0.048^{* *}$ & 0.0063249 & 1.090817 & \\
AGMT & -0.1758641 & 1.527747 & -0.12 & 0.909 & -3.322318 & 2.97059 & \\
Cons & -131.8372 & 46.30407 & -2.85 & 0.009 & -227.2022 & -36.47217 & \\
\hline
\end{tabular}

Source: Results obtained from Stata $12^{\text {th }}$ edition (2017). ${ }^{* *},{ }^{* *}$, ${ }^{*}$ indicates significant at $p<0.01, p<0.05$, and $p<0.1$ respectively. 
crops will mean a fall in food supply thereby limiting the chances of achieving food security in Nigeria. In addition to this, Nigeria must begin to adopt policies that will grow her capital formation which can positively impact on crop production, since this study has shown that it will have a significant impact on crop out in Nigeria, failure to do this will cause food supply to reduce thereby leading to increase in prices and hence poverty. The study also shows that all variables have a significant impact on crop output except AGMT which indicates an insignificant relationship, even though AGMT presented a significant relationship in the short run and is inappropriately signed negating our apriori expectation, this study believes that the deviation of the sign of the coefficient from apriori expectation may be due to the fact that the high cost of importation of agricultural machines and tractors may act as a drain on the economy financially therefore negatively affect crop output. The result also indicates that the explanatory variables have explained the dependent variable crop output by $94 \%$ in the short run and $80 \%$ in the long run. All the results have shown evidence that the model is well fitted with an acceptable probability value of less than $5 \%$ which also validates the model.

The values of correlation below further indicates the direction and strength of relationship between CRPI and other variables that were studied, for example the correlation between Crop production index (CRPI) and carbon dioxide emission $\left(\mathrm{CO}_{2} \mathrm{E}\right)$ is $8.48 \%$ and negative which shows that $\mathrm{CO}_{2} \mathrm{E}$ is a variable that must not be taken for granted in crop production efforts. Again, the correlation between Crop production index (CRPI) and carbon emission (due to manufacturing activities) CARBE is $26 \%$ and negative which indicates a strong relationship which is in line with our apriori expectations. This also means that the value CARBE must be observed closely and mitigation adopted to forestall decrease in crop production. The correlation between Crop production index and (CRPI), temperature (TEMP) and rainfall in Table 6 above has shown 33\% and positive as well as $38 \%$ and negative respectively. This generally shows that the effects climate change variables on crop output must be taken seriously by all stakeholders

Table 6. Correlation of CRPI $\mathrm{CO}_{2}$ E EAPA LAEI CARBE GCF TEMP RAIN AGMT (obs $=34)$.

\begin{tabular}{ccccccccc}
\hline & CRPI & $\mathrm{CO}_{2} \mathrm{E}$ & EAPA & LAEI & CARBE & GCF & TEMP & RAIN \\
\hline CRPI & 1.0000 & & & & & & & \\
CO2E & -0.0848 & 1.0000 & & & & & & \\
EAPA & 0.4518 & 0.5509 & 1.0000 & & & & & \\
LAEI & 0.6263 & 0.4545 & 0.6888 & 1.0000 & & & & \\
CARBE & -0.2645 & -0.1192 & 0.1978 & -0.0494 & 1.0000 & & & \\
GCF & -0.3228 & -0.6224 & -0.8679 & -0.7968 & -0.2075 & 1.0000 & & \\
TEMP & 0.3840 & -0.3567 & -0.0974 & -0.0380 & -0.0736 & 0.1741 & 1.0000 & \\
RAIN & 0.3345 & -0.2343 & -0.0057 & 0.1662 & 0.2681 & -0.0313 & 0.2970 & 1.0000 \\
AGMT & 0.3098 & 0.4378 & 0.4660 & 0.6034 & 0.1275 & -0.5639 & -0.5639 & \\
\hline
\end{tabular}

Source: Results obtained from Stata $12^{\text {th }}$ edition (2017). 
Table 7. Summary statistics of CRPI $\mathrm{CO}_{2}$ E EAPA LAEI CARBE GCF TEMP RAIN AGMT.

\begin{tabular}{cccccc}
\hline Variable & Obs & Mean & Std. Dev & Min & Max \\
\hline CRPI & 34 & 60.98794 & 30.48982 & 0 & 105.31 \\
CO2E & 34 & 0.5440604 & 0.2611585 & 0 & 0.9021949 \\
EAPA & 34 & $1.18 \mathrm{e}+07$ & $3,000,171$ & 0 & $1.29 \mathrm{e}+07$ \\
LAEI & 34 & $226,176.5$ & $80,710.28$ & 0 & 293,000 \\
CARBE & 34 & 52.29206 & 16.48206 & 31.24 & 82.12 \\
GCF & 34 & 5699.666 & $17,683.66$ & 8.8 & $89,043.62$ \\
TEMP & 34 & 35.29118 & 3.374536 & 29.5 & 43.1 \\
RAIN & 34 & 113.4912 & 11.49267 & 90 & 138 \\
AGMT & 34 & 4.309235 & 2.325278 & 0 & 6.969697 \\
\hline
\end{tabular}

Source: Results obtained from Stata $12^{\text {th }}$ edition (2017).

to achieve development. This result of correlation matrix further asserts the authenticity of the findings above.

The values of the standard deviation of the variables in Table 7 above have shown the extent of variations in the variables studied. Our results indicates moderate variations in climate change variables especially CARBE, TEMP, AND RAIN. This means that experts and other stakeholders must be up and doing in other to provide knowledge to farmers that can mitigate the effects of climate variability.

Figure 1 below is stability test for the model. All residuals are stable if the cumulative sums are located between the two standard deviations, but if the cumulative sums are outside the band, it means the parameters used in the model are not stable. For this model, the cumulative sums are plotted against the time. It can be seen that the model is stable, as it is maintained within the 5 percent significance level under the observation period (Table 8).

Null hypothesis: Residuals are not serially correlated.

The $p$ value is greater than 5 percent, therefore we accept the null hypothesis that there is no serial correlation. The residuals are not serially correlated and this is a desirable result. This test authenticates our model.

The findings of this study on rainfall is not in agreement with the findings of Terfa [28] which states that rainfall did not significantly influence food supply both in the short run and the longrun, whereas temperature in this study show an insignificant relationship with crop output in the shortrun, there is evidence of a significant relationship in the longrun. Furthermore, this study agrees with the findings of Eregha, Babatolu, and Akinnubi [29] on the variable carbon emission which states that carbon emission has a significantly negative influence on crop output.

The results in Tables 4-6 above implies that given the significant effects of climate change on crop output, policy makers and appropriate government agencies must begin to pay keen attention to diverse methods of crop production strategies that can mitigate the negative effects of climate change otherwise crop output will fall. A fall in crop output will lead to increase in prices of food which may lead to reduced demand resulting to hunger, reduced productivity, social tension and underdevelopment in Nigeria. 


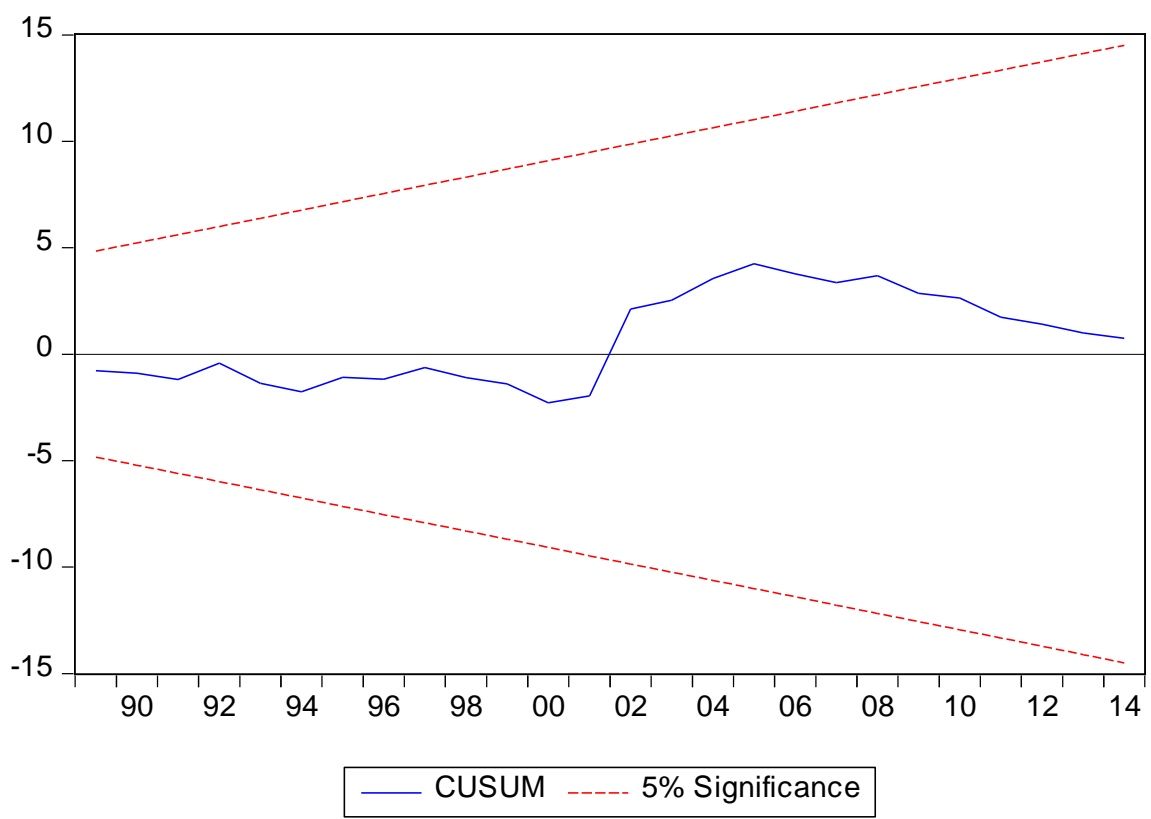

Figure 1. Stability test. Source: Results obtained from E-views version 9 (2017).

Table 8. Serial correlation LM test.

\begin{tabular}{cccc}
\hline F-statistic & 0.049159 & Prob. F(2,24) & 0.9521 \\
\hline Obs $^{\star}$ R-Squared & 0.134636 & Prob. Chi-Square (2) & 0.9349 \\
\hline
\end{tabular}

Source: Results obtained from E-views version 9 (2017).

\section{Conclusions and Recommendations}

In the short-run, only rainfall have shown a significantly positive relationship on crop production while the rest of the climate change factors like carbon dioxide, temperature, and carbon emission (due to manufacturing and industrial activities) indicated insignificant influence on crop production within the period studied. The error correction term have indicated that the system in case of shock within the economy, can recover or equilibrate in the long run at the rate of $23 \%$ per annum. However, in the long-run the study further provides evidence that among climate change factors that we studied, carbon dioxide emission, rainfall, temperature and carbon emission (due to manufacturing and industrial activities) will have a significant influence on crop production. The study also found that the influence of carbon dioxide emission as well as carbon emission (due to manufacturing and industrial activities) has indicated a negative influence on crop production which is in line with the study expectations. Very importantly too, the other determinants of crop production studied along with climate change factors like gross capital formation, economically active population in agriculture and land area equipped for irrigation will have a significantly positive influence on crop production in Nigeria in the long-run, only agricultural machines and tractors have shown an insignificantly negative influence on crop production.

To forestall these effects, the study recommends that policy makers are en- 
couraged to formulate policies that will aid farmers towards adaptation to farming practices that can mitigate the effects of climate change. For example, development of crop seedlings through the use of biotechnology that produces within short gestation, also crops that do well even in high temperature and are resistant to effects of carbon and carbon dioxide emission. This can be achieved through formulation of policies that can ensure more effective funding of research institutes and biotechnology Centre of Nigeria. Governments and other relevant agencies should also design programmes that can motivate the masses to increase their involvement in crop production as well as provision of irrigation facilities to provide moisture to crops therefore encourage all season farming. These recommendations are germane towards achieving food security, raising the welfare standards of farmers to further encourage productivity and reduce food prices and imports in Nigeria.

\section{References}

[1] African Partnership Forum (AFP) (2011) Climate Change and Africa. 8th Meeting of African Partnership Forum, Berlin, 22-23 May 2011, 22-23.

[2] Omojolaibi, J.A. (2014) Climate Change and Sustainability Development in Sub-Saharan Africa, an Application of Panel Coointigration to Some Selected Countries. In: Iregha P.B. Babatolu J.S. and Akinnubi, R.T., Eds., Climate Change and Crop Production in Nigeria: An Error Correction Modelling Approach. International Journal of Energy Economics and Policy, 4, 297-311.

[3] Odingo, R.S. (2002) Climate Change and Economic Development. Challenges and Opportunities for Africa in the Decade Ahead. An AERC Senior Policy Seminar X. Presented in a Seminar, Addis Ababa.

[4] IPCC (2007b) Climate Change: Synthesis Report. Cambridge University Press, Cambridge.

[5] Trenberth, K.E., Jones, P.D., Amberje, P., Bojarin, R., Easterling, D., Klein Tank, A., Parker, D., Rahimzadeh, F., Renwick, J.A., Rusticucci, M., Soden, B. and Zhai, P. (2007) Observations: Surface and Atmospheric Climate Change. In: Hoskins, B.J. Karl T.R., and Jallow, B., Eds., Climate Change 2007: The Physical Science Basis, Contribution of Working Group 1 to the Fourth Assessment Report of the IPCC. Cambridge University Press, Washington, 235-236.

[6] WTO-UNEP (2009) World Trade Organization and the United Nations Environmental (WTO-UNEP). Report on Trade and Climate Change. www.Wt.org/English/res_../booksp_etrade_climatechange_e.pdf

[7] Intergovernmental Panel on Climate Change IPCC (2007a) Fourth Assessment Report, Climate change Cambridge UK. Cambridge University, Press for Intergovernmental Panel on Climate Change, Cambridge.

[8] Central Bank of Nigeria Statistical Bulletin (2007) A Classified Government Document on Statistics.

[9] Agba D.Z. (2015) Formal Agricultural Lending and the Response of Irish Potato Output in Plateau State. Journal of Management Sciences, 4, 331-318.

[10] Tunde A.M., Usman, B.A. and Olawapo, V.O. (2011) Effects of Climate Change variables on Crop Production in Patigi LGA, Kwara State, Nigeria. Journal of Geography and Regional Planning, 36, 695-700. 
[11] Adger, W.N., Huq, S., Brown, K., Conway, D. and Hulme, M. (2003) Adaptation to Climate Change in the Developing World. Progress in Development Studies, 3, 179-195. https://doi.org/10.1191/1464993403ps060oa

[12] Kurukulasuriya, P. and Mendelsohn, R. (2008) A Ricardian Analysis of the Impact of Climate Change on African Cropland. African Association of Agricultural Economists, 2, 2.

[13] Central Bank of Nigeria (2011) The Statistical Bulletin of Central Bank of Nigeria. CBN, Abuja.

[14] Ayinde, O.E., Muchie, M. and Olatunji, G.B. (2011) Effect of Climate Change on Agricultural Productivity in Nigeria: A Cointegration Modeling Approach. Journal of Human Ecology, 35, 185-194.

[15] Organisation for Economic Cooperation and Development (OECD) (2017) Crop Production (Indicator). OECD, Paris.

[16] UNFCCC (2007) Climate Change Impacts, Vulnerabilities and Adaptation in Developing Countries. Climate Change Secretariat, Bonn.

[17] Carey, C. (2009) The Impacts of Climate Change on the Annual Cycles of Birds. Philosophical Transactions of the Royal Society B, 364, 3321-3330. https://doi.org/10.1098/rstb.2009.0182

[18] IPCC (2013) Climate Change; The Physical Science Basis, Summary for policy makers, Observed Changes in the Climate System P 15, IN IPCC AR5, WG1. IPCC. https://www.ipcc.ch/pdf/assessment-report/ar5/wg1/WGIAR5_SPM_brochure_en.p $\underline{\mathrm{df}}$

[19] Pielke, S.R. (2009) Climate Change: The Need to Consider Human Forcings besides Greenhouse Gases. Earth Observation Satellite (EOS), 90, 413. https://doi.org/10.1029/2009eo450008

[20] Gray, W.M. (2009) Climate Change: Driven by the Ocean, Not Human Activity. 2nd Annual Heartland Institute Conference on Climate Change, New York, 8-10 March 2009.

http://tropical.atmos.colostate.edu/Includes/Documents/Publications/gray2009.pdf

[21] Bast, J.L. (2010) Seven Theories of Climate Change. The Heartland Institute, Arlington Heights, Illinois.

http://www.physicsclassroom.com/class/circles/Lesson-4/Kepler-s-Three-Laws

[22] IPCC (2000) Special Report on Emission Scenarios. Cambridge University Press, Cambridge.

[23] Mendelsohn, R. and Dinar, A. (1999) Climate Change, Agriculture, and Developing Countries: Does Adaptation Matter? The World Bank Research Observer, 14, 277-293. https://doi.org/10.1093/wbro/14.2.277

[24] Mathauda, S.S., Mavi, H.S., Bhangoo, B.S. and Dhaliwal, B.K. (2001) Impacts of Projected Climate Change on Rice Production in Punjab (India). Tropical Ecology, 41, 95-98.

[25] Torvanger, A., Twena, M. and Romstad, B. (2004) Climate Change Impacts on Agricultural Productivity in Norway. Centre for International Climate and Environment Research Working Paper 10. Centre for International Climate and Environment Research, Oslo.

[26] Basak, J.K., Ali, A., Islam, N. and Rashid, A. (2010) Assessment of the Effects of Climate Change on Boro Rice Production in Bangladesh Using DSSAT Model. Journal of Civil Engineering, 38, 95-108. 
[27] Agboola,T. and Ojeleye, D. (2007) Climate Change and Food Production in Ibadan. Nigeria Afi. Crop Sciconfer Prod, 8, 1423-1433.

[28] Terfa, A. (2012) Climate Change and Food Supply in Nigeria. Nigerian Journal of Economics and Social Studies, 54, 209.

[29] Eregha, P.B., Babatolu, J.S. and Akinnubi, R.T. (2014) Climate Change and Crop Production in Nigeria: An Error Correction Modelling Approach. International Journal of Energy Economics and Policy, 4, 297-311.

[30] Central Bank of Nigeria Statistical Bulletin (2015) Domestic Production, Consumption and Prices. Central Bank of Nigeria, Abuja.

[31] Oyewole, J.A., Thompson, A.M., Akinpelu, J.A. and Jegede, O.O. (2014) Variation of Rainfall and Humidity in Nigeria. Journal of Environment and Earth Science, 4, 2224-3216.

[32] World Data Atlas (2014) Nigeria: CO2 Emissions from Manufacturing Industries and Construction (Million Metric Tons). World Data Atlas. https://knoema.com/atlas/topics/Emissions/datasets

[33] World Development Indicator (2014). International Bank for Reconstruction and Development. The World Bank, Washington D.C. www.worldbank.org

[34] Bond, S., Leblebicioglu, A. and Schiantarelli, F. (2010) Capital Accumulation and Growth. A New Look at Empirical Evidence. Journal of Applied Econometrics, 25 1073-1099. https://doi.org/10.1002/jae.1163

[35] Engle, R.F. and Granger, C.W.J. (1987) Co-Integration and Error Correction: Representation, Estimation, and Testing. Econometrica, 55, 251-276. https://doi.org/10.2307/1913236

Submit or recommend next manuscript to SCIRP and we will provide best service for you:

Accepting pre-submission inquiries through Email, Facebook, LinkedIn, Twitter, etc. A wide selection of journals (inclusive of 9 subjects, more than 200 journals)

Providing 24-hour high-quality service

User-friendly online submission system

Fair and swift peer-review system

Efficient typesetting and proofreading procedure

Display of the result of downloads and visits, as well as the number of cited articles

Maximum dissemination of your research work

Submit your manuscript at: http://papersubmission.scirp.org/

Or contact ajcc@scirp.org 